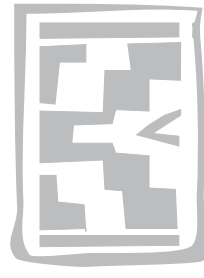

\title{
Studies on the toxicity of an aqueous extract of the leaves of Abrus precatorius in rats
}

\author{
A.A. ADEDAPO ${ }^{1}$, O.A. OMOLOYE ${ }^{1}$ and O.G. OHORE ${ }^{2}$
}

\begin{abstract}
ADEDAPO, A.A., OMOLOYE, O.A. \& OHORE, O.G. 2007. Studies on the toxicity of an aqueous extract of the leaves of Abrus precatorius in rats. Onderstepoort Journal of Veterinary Research, 74:3136

The toxic effects of an aqueous extract of Abrus precatorius were studied in 20 male white rats over a period of 18 days. The rats were divided into four groups of five rats per group. Those in Group A served as controls while the rats in Groups B, C and D were dosed per os with $400 \mathrm{mg} / \mathrm{kg}, 800 \mathrm{mg} / \mathrm{kg}$ and $1600 \mathrm{mg} / \mathrm{kg}$ of the extract, respectively. Blood samples were collected for haematological and biochemical analysis and specimens of the liver, kidney and testes were taken for histopathological studies.

The study showed that the extract of $A$. precatorius caused decreased levels of packed cell volume, haemoglobin concentration, red blood cell count, white blood cell count, mean corpuscular volume and mean corpuscular haemoglobin. The extract also resulted in increased levels of total serum protein, albumin, alanine amino transaminase, aspartate amino transferase, alkaline phosphatase and total bilirubin. Histologically, testicular degeneration characterized by decreased numbers of lining cells of the epithelium as well as reduction in sperm cells with presence of scattered Sertoli cells were noted. The study thus showed that aqueous extract of Abrus precatorius is toxic and caution should be exercised in its use for medicinal purpose.
\end{abstract}

Keywords: Abrus precatorius, haematology, histopathology, rats, serum biochemistry

\section{INTRODUCTION}

Abrus precatorius is a popular medicinal plant. Many medicinal uses are ascribed to this plant. The leaves, stem and roots are sweet-tasting due to the presence of glycyrrhizin, of which about $9-10 \%$ is in the leaf (Burkill 1997). It has been used in the treatment of coughs and vomiting in different animal species and therapeutic dose is said to be about $0.01 \mathrm{mg} / \mathrm{kg}$ body mass, above which toxicity results (Gunsolus 1995). Children are attracted by its brightly-coloured

1 Department of Veterinary Physiology, Biochemistry and Pharmacology, University of Ibadan, Ibadan, Nigeria

2 Department of Veterinary Pathology, University of Ibadan, Ibadan, Nigeria

Accepted for publication 27 September 2006-Editor seeds and in some countries they play with the seeds and use them in school in their handiwork and to count. Necklaces and other ornaments made from the seeds are worn by both children and adults. The seeds are also used for the treatment of diabetes mellitus and chronic nephritis (Burkill 1997; Cheeke 1998). The plant is also used in traditional medicine for the treatment of scratches, sores, and wounds caused by dogs, cats, and mice. It is also used with other ingredients to treat leucoderma.

The leaf is commonly chewed or sucked to obtain its sweet taste. It is boiled with food e.g. cereal pulp, as a sweetener and even as a vegetable. Fresh leaves may be pressed on the gum for sores in the mouth. The leaf is even used in many countries in preparations for skin cancer. The leaf has anodynal 
properties and a calming effect on the central nervous system (Burkill 1995). The leaves are used for their anti-suppurative property. They are ground with lime and applied to acne sores, boils and abscesses.

The plant is also traditionally used to treat tetanus and to prevent rabies (Watt \& Breyer-Brandwijk 1962). Various African tribes use powdered seeds as oral contraceptives (Watt \& Breyer-Brandwijk 1962) while boiled seeds are eaten in certain parts of India (Rajaram \& Janardhanan 1992).

Abrus precatorius contains ricin and abrin, which are among the most potent toxins described. Seeds and foliage are all poisonous. In early stages of ricin toxicosis, animals were dull, later they showed signs of incoordination and in severe cases, there was profuse swelling, tetanic spasms of the muscles and convulsion. Clinical toxicosis reflects primary damage to the gastrointestinal tract and includes violent gastroenteritis followed by weakness and death (Cheeke \& Shull 1985; Galey 1996; Adedapo 2002). Abrin, which consists of abrus agglutinin (a haemaglutinin), and toxic lectins abrins $a$ to $d$ are the five toxic glycoproteins found in the seeds (Budavari 1989; Windholz 1989). Abrin-a, one of four isoabrins from the plant, has the highest inhibitory effect on protein synthesis and consists of an A chain of 250 amino acids and a B chain of 267 amino acids (Tahirov, Lu \& Liaw 1994). The $L_{50}$ of abrin injected in mice is less than $0.1 \mu \mathrm{g} / \mathrm{kg}$, making abrin one of the most toxic substances known (Klaassen 2001). Abrin is present in the leaf and is known to have action on hyperactivity of the system (Burkill 1995).

Because of the hard and relatively impermeable coat of the mature seeds, they are considerably less toxic if swallowed whole. In fact it is claimed that all parts of this plant is toxic (Cheeke 1998). However, they are more dangerous when the seeds are chewed or sucked because the toxic elements in the seeds are extracted and mixed with enzymes. Clarke \& Clarke (1975) reported that the black and red seeds of $A$. precatorius, a perennial vine found throughout the tropics, contain the very poisonous phytotoxin, abrin, a substance very similar to ricin of the castor-oil seed. Cheeke (1998) also showed that the plant is native to the tropics and that it grows by the seashore among the undergrowth and in hedges.

This study seeks to establish the possible toxic effects of the leaves of this plant on animals using haematology, serum biochemistry and histopathology as indices of toxicosis especially that most works were done on the seeds rather than the leaves.

\section{MATERIALS AND METHODS}

\section{Animals and experimental designs}

The animals used in this study were 20 adult male Wistar rats of between 180 and $250 \mathrm{~g}$ body mass. The rats were maintained at the Experimental Animal House of the Faculty of Veterinary Medicine, University of Ibadan. They were kept in rat cages and fed commercial rat pellets (Ladokun and Sons Livestock Feeds, Nigeria Ltd.) and allowed free access to clean fresh water.

The twenty animals were allotted into four groups (A to $D)$ of five animals per group. While the Group A rats served as control experiment, Groups B, C and $\mathrm{D}$ animals were administered with $400 \mathrm{mg} / \mathrm{kg}, 800$ $\mathrm{mg} / \mathrm{kg}$ and $1600 \mathrm{mg} / \mathrm{kg}$, doses of the extract, respectively.

\section{Preparation of the aqueous crude extract of Abrus precatorius}

Freshly harvested leaves of the plants were used for the preparation of the extract. The plants were authenticated at the herbarium of Department of Botany and Microbiology, University of Ibadan, Nigeria. The leaves were weighed and macerated using mortar and pestle. A specific quantity of water was added to ensure proper maceration and to also obtain an extract of $500 \mathrm{mg} / \mathrm{m} \ell$ concentration. Thereafter, the solution was filtered through Whatman filter paper, and the filtrate was then administered to the rats per os at predetermined dosages daily using stomach canula for 18 days. The control group received distilled water instead of extract.

\section{Technique for obtaining blood and serum samples}

Paired blood samples were collected by cardiac puncture from rats anaesthetized with diethyl ether into heparinised and non-heparinised bottles for haematological and serum biochemical studies, respectively. Blood samples collected into clean nonheparinised bottles were allowed to clot and serum was separated from the clot and centrifuged according to groups into clean bottles for the biochemical analyses.

\section{Determination of haematological parameters}

Determination of haemoglobin concentration was as described by Schalm, Jain \& Carroll (1975) using the cyanomethaemoglobin method. Packed cell volume (PCV) was determined by conventional method of filling the capillary tubes with blood as described 
by Schalm et al. (1975). Erythrocyte count was determined by the haemocytometer method as described by Coles (1986). Total leucocytes and differential leucocyte counts were also determined. Erythrocytes indices were determined from values obtained for RBC count, haemoglobin concentration and PCV values.

\section{Determination of serum biochemical parameters}

Total protein was measured using the biuret reaction while albumin was measured by colorimetric estimation using the Sigma Diagnostics albumin reagent (Sigma Diagnostic $\AA$, UK), which contained bromocresol green (BCG). Globulin was estimated as the difference between total protein and albumin.

Aspartate aminotransferase (AST), alkaline phosphatase (ALP) and alanine aminotransferase (ALT) were determined on a photoelectric colorimeter (Gallenkamp and Sons Ltd; England) as described by Toro \& Ackermann (1975) and Duncan, Prasse \& Mahaffey (1994). Serum urea and creatinine levels were also determined on a photoelectric colorimeter (Gallenkamp and Sons Ltd, England) as described by Toro \& Ackermann (1975) and Coles (1986).

\section{Histopathology}

The liver, kidney and testes of all the animals were fixed in $10 \%$ buffered formalin in labeled bottles, and processed routinely for histological examination. Tissues embedded in paraffin wax were sectioned $5 \mu \mathrm{m}$ thick, stained with haematoxylin and eosin, mounted on glass slides and then examined under a standard light microscope.

\section{Statistical analysis}

The data were subjected to the Student's t-test and were considered significant at $P<0.05$ (Essex-Sorlie 1995).

\section{RESULTS}

\section{Haematological changes}

The haematological changes produced in rats given different doses of $A$. precatorius are presented in Table 1. Rats given $400 \mathrm{mg} / \mathrm{kg}, 800 \mathrm{mg} / \mathrm{kg}$ and 1600 $\mathrm{mg} / \mathrm{kg}$ doses of the extract showed a significant decrease $(P<0.05)$ in the mean PCV level relative to the control, although these values did not indicate anaemia. The effect of the extract on the haemoglobin concentration also followed a similar decrease in rats treated with 400 and $1600 \mathrm{mg} / \mathrm{kg}$ doses but not with the $800 \mathrm{mg} / \mathrm{kg}$. All the dose levels caused a significant $(P<0.05)$ decrease in red blood cell counts as well as the MCV when compared to the control values.

The leucogram showed that there was a significant decrease $(P<0.05)$ in white blood cell count in rats given $400 \mathrm{mg} / \mathrm{kg}$ relative to the controls, while a significant decrease $(P<0.05)$ was obtained for lymphocyte counts in rats dosed with 400 and $800 \mathrm{mg} / \mathrm{kg}$ of extract. There was a relative decrease in the neutrophil counts in rats dosed with $400 \mathrm{mg} / \mathrm{kg}$ of $A$. precatorius extract.

\section{Serum biochemical changes}

The serum biochemical changes observed in rats given different doses of the extracts are shown in

TABLE 1 Effects of the graded doses of the aqueous extracts of $A$. precatorius on haematological parameters of rats $(n=5)$

\begin{tabular}{|l|c|c|c|c|}
\hline Parameters & Control (A) & $\mathbf{4 0 0} \mathbf{~ m g / k g ~ ( B ) ~}$ & $\mathbf{8 0 0} \mathbf{~ m g / k g ~ ( C ) ~}$ & $\mathbf{1 6 0 0 ~} \mathbf{~ m g / k g}(\mathrm{D})$ \\
\hline $\mathrm{PCV}(\%)$ & $54.5 \pm 4.5$ & $36.3 \pm 3.3^{\mathrm{a}}$ & $40.6 \pm 2.5^{\mathrm{a}}$ & $34.0 \pm 0.5^{\mathrm{a}}$ \\
$\mathrm{Hb}(\mathrm{g} / \mathrm{L})$ & $13.8 \pm 4.5$ & $11.9 \pm 1.5$ & $13.1 \pm 0.8$ & $11.3 \pm 0.2^{\mathrm{b}}$ \\
$\mathrm{RBC}\left(\mathrm{X} 10^{12} \mathrm{~g} / \mathrm{L}\right)$ & $8.6 \pm 0.2$ & $6.9 \pm 0.2^{\mathrm{c}}$ & $6.8 \pm 0.5^{\mathrm{c}}$ & $6.2 \pm 0.2^{\mathrm{c}}$ \\
$\mathrm{MCV}(\mathrm{fl})$ & $65.4 \pm 2.9$ & $52.7 \pm 4.2^{\mathrm{e}}$ & $59.6 \pm 2.7^{\mathrm{e}}$ & $55.5 \pm 2.4^{\mathrm{e}}$ \\
$\mathrm{MCHC}(\mathrm{g} / \mathrm{dl})$ & $32.7 \pm 0.2$ & $32.9 \pm 0.6$ & $32.5 \pm 0.5$ & $32.5 \pm 0.1$ \\
$\mathrm{MCH}(\mathrm{pg})$ & $21.3 \pm 0.9$ & $17.2 \pm 1.9^{\mathrm{e}}$ & $19.2 \pm 0.8^{\mathrm{e}}$ & $18.0 \pm 0.6^{\mathrm{e}}$ \\
WBC (X109/L) & $12.0 \pm 1.4$ & $7.1 \pm 2.1^{\mathrm{f}}$ & $12.5 \pm 0.1$ & $12.2 \pm 0.1$ \\
Lymphocytes (x109/L) & $7.7 \pm 1.2$ & $5.0 \pm 1.1^{\mathrm{g}}$ & $6.4 \pm 0.6^{\mathrm{g}}$ & $7.3 \pm 2.1$ \\
Neutrophils (x109/L) & $4.1 \pm 1.1$ & $2.0 \pm 0.6^{\mathrm{h}}$ & $6.0 \pm 0.3^{\mathrm{h}}$ & $4.6 \pm 0.6$ \\
Monocytes (x109/L) & $0.2 \pm 0.1$ & $0.1 \pm 0.1$ & 0 & $0.1 \pm 0.1$ \\
Eosinophils (x109/L) & 0 & $0.1 \pm 0.1$ & $0.1 \pm 0.1$ & $0.1 \pm 0.1$ \\
\hline
\end{tabular}

Superscripted items indicate significant values Note: Mean \pm S.D. 
Toxicity of an aqueous extract of leaves of Abrus precatorius in rats

TABLE 2 Effects of the graded doses of $A$. precatorius on the serum biochemical parameters of rats $(n=5)$

\begin{tabular}{|c|c|c|c|c|}
\hline Parameters & Control (A) & $400 \mathrm{mg} / \mathrm{kg}(\mathrm{B})$ & $800 \mathrm{mg} / \mathrm{kg}(\mathrm{C})$ & $1600 \mathrm{mg} / \mathrm{kg}(\mathrm{D})$ \\
\hline Total protein (g/L) & $6.5 \pm 0.1$ & $6.6 \pm 0.1^{a}$ & $7.8 \pm 0.1^{a}$ & $26.5 \pm 4.4^{a}$ \\
\hline Albumin $(g / L)$ & $2.5 \pm 0.1$ & $3.4 \pm 0.1^{b}$ & $3.2 \pm 0.1^{b}$ & $10.0 \pm 3.2^{b}$ \\
\hline Globulin (g/L) & $4.0 \pm 0.3$ & $3.2 \pm 0.1^{c}$ & $4.6 \pm 0.1$ & $16.5 \pm 4.2^{\mathrm{c}}$ \\
\hline $\operatorname{ALT}(\mathrm{U} / \mathrm{L})$ & $112.0 \pm 1.4$ & $109.0 \pm 1.4^{\mathrm{d}}$ & $118.0 \pm 1.6^{d}$ & $368.8 \pm 2.6$ \\
\hline AST (U/L) & $520.0 \pm 1.4$ & $442 \pm 1.4^{\mathrm{e}}$ & $660.0 \pm 1.6^{\mathrm{e}}$ & $1904.8 \pm 8.6^{e}$ \\
\hline ALP (U/L) & $220.0 \pm 1.4$ & $62.0 \pm 1.4^{\dagger}$ & $268.3 \pm 2.5^{f}$ & $750.0 \pm 5.6^{f}$ \\
\hline Total bilirubin $(\mu \mathrm{mol})$ & $0.3 \pm 0.1$ & $0.1 \pm 0.1^{\dagger}$ & $0.3 \pm 0.01$ & $0.9 \pm 0.4^{f}$ \\
\hline Conj. bilirubin ( $\mu \mathrm{mol})$ & $0.1 \pm 0.1$ & $0.02 \pm 0.01^{g}$ & $0.1 \pm 0.02$ & $0.4 \pm 0.2^{f}$ \\
\hline Unconj. bilirubin ( $\mu \mathrm{mol})$ & $0.2 \pm 0.01$ & $0.13 \pm 0.05$ & $0.2 \pm 0.01$ & $0.5 \pm 0.04^{f}$ \\
\hline
\end{tabular}

Superscripted items indicate significant values $(P<0.05)$

Note: Mean \pm S.D.

Table 2. It was only Group D animals $(1600 \mathrm{mg} / \mathrm{kg}$ dose) that showed a significant increase $(P<0.05)$ in the levels of total protein, albumin and globulin. Enzyme assay showed that there was a significant increase $(P<0.05)$ in the level of ALP in rats administered with $1600 \mathrm{mg} / \mathrm{kg}$ extract when compared to that of control. Rats dosed with $400 \mathrm{mg} / \mathrm{kg}$ however, showed a significant decrease $(P<0.05)$ in ALP when compared with the control group. The levels of AST and ALT were also significantly elevated in rats dosed with $1600 \mathrm{mg} / \mathrm{kg}$ extract.

Animals in Group B (800 mg/kg) showed significant reduction in the levels of total bilirubin and conjugated bilirubin. Group D (1600 mg/kg) animals on the other hand, showed a significant increase $(P<$ 0.05 ) in the levels of total bilirubin, conjugated bilirubin and unconjugated bilirubin relative to the control (Table 2).

\section{Histopathological studies}

Histological examination revealed foci of lymphocytic infiltration at the portal areas of the liver. Rats given the extract of the plant had scanty spermatozoa in the epididymis. There was severe degeneration of the epithelium of the seminiferous tubules characterized by disappearance of lining epithelium and presence of scattered Sertoli cells. A few spermatogonia and a few intratubular multinucleated giant cells were also observed.

\section{DISCUSSION AND CONCLUSIONS}

There was a relative decrease in PCV, RBC and $\mathrm{MCV}$ in rats that were administered $400 \mathrm{mg} / \mathrm{kg}, 800$ $\mathrm{mg} / \mathrm{kg}$ and $1600 \mathrm{mg} / \mathrm{kg}$ doses of $A$. precatorius extract. It thus showed that animals that browse the leaves of this plant may be subjected to depression in erythopoiesis and possibly anaemia over prolonged exposure. This might be as a result of the abrin content of the plant, which consists of abrus agglutinin (a haemaglutinin), and toxic lectins abrins $a-d$, which are the five toxic glycoproteins found in the seeds (Budavari 1989; Windholz 1989). The effects of anaemia are greatly influenced by its severity, duration and rate of development (Taiwo \& Anosa 1995; Macfarlane, Reid \& Callander 2001). It may thus be safe to conclude that the aqueous extract of the leaves of $A$. precatorius can cause toxic effects on the red blood cells of rats.

The study showed that there was a significant decrease in total white blood cell count in the group dosed with $400 \mathrm{mg} / \mathrm{kg}$. Toxic plants do not produce a direct effect on the white blood cells, such as neutrophils, lymphocytes, eosinophils and monocytes (Swenson \& Reece 1993). However, in contrast, excessive ingestion of a wide variety of plants or their products has been found to cause hypoproliferative or non-regenerative anaemia. This is a stem cell disorder, characterized by reduced production of all blood components in the absence of a primary disease process infiltrating the bone marrow or suppressing haemopoiesis (Olsen, Keller \& Gerken 1984). The cause of the decrease in the low dose group in this study could not be ascertained.

Group B showed a significant decrease in the level of lymphocytes, which implies that lymphocytes that participate in immune responses have been suppressed. It therefore means that the body is vulnerable to infections (Macfarlane et al. 2001). There was relative decrease in the level of neutrophils in the Group B rats while the Groups C and D rats showed an apparent increase, which might have been due to stress leading to demargination of neutrophils into circulation (Bush 1991). 
There is increase in the level of ALP in the Groups $C$ and $D$ animals but a decrease in Group B. This shows that at $800 \mathrm{mg} / \mathrm{kg}$ and $1600 \mathrm{mg} / \mathrm{kg}$, the plant extract can cause enzyme induction. An increased ALP may be due to hepatic insufficiency, cholestasis or obstruction of the bile ducts (Carlson 1996).

There was also an increase in AST level following administration of the extract at $800 \mathrm{mg} / \mathrm{kg}$ and 1600 $\mathrm{mg} / \mathrm{kg}$ doses. The increase in AST may be due to hepatic insufficiency or muscle infection (Abatan, Arowolo \& Olorunsogo 1996). There was also an increase in ALT following administration of the extract at $800 \mathrm{mg} / \mathrm{kg}$ and $1600 \mathrm{mg} / \mathrm{kg}$, which may be as a result of liver involvement (Duncan et al. 1994; Nelson \& Cox 2000).

There is a significant increase in the total protein level in Groups C and D. There was an increase in the albumin level in all three groups, but since a rise in albumin rarely occurs (Bush 1991), the increase may be associated with dehydration and shock resulting in the elevation of the values of this parameter. There is significant increase in globulin in Group D but a significant decrease in Group B.

The total bilirubin was increased in Group D compared to the value of the control group. Conjugated bilirubin to unconjugated ratio is less than $50 \%$. Conjugated bilirubin is low, probably because of hepatic necrosis whereby ability of the liver to conjugate bilirubin is reduced particularly in rats administered with $800 \mathrm{mg} / \mathrm{kg}$. Increase unconjugated bilirubin level may be a pointer to hepatic injury (Knoll 1998).

Histological examination revealed foci of lymphocyte infiltration in the portal areas of the liver while the testes showed marked testicular degeneration and severe disorganization of seminiferous tubules, which were devoid of spermatic cells.

Testicular degeneration involves a retrogressive change in the germinal epithelium of the seminiferous tubules (Macfarlane et al. 2001). The pattern of testicular damage observed in this study is consistent with the effects of phoxim (Atef, Noussef, Ramadam, Nawito, El-Sayed \& El-Rahman 1995), oestradiolvalerate (Kohler-Samouilidis, Papioannou, Kotsaki-Kovatsi \& Vadarakis 1998) and Curcuma comosa extract (Piyacchaturawati, Timinkul \& Suksamran 1998). As the interstitium was devoid of Leydig cells, the histological changes observed may also be due to decreased production of testosterone known to be responsible for normal testicular architecture (Akinloye, Igharha, Olaniyi, Alaka \& Oke 2000).
In the case of the liver, there were cases of lymphocytic infiltration at the periportal area indicating a toxic effect, and probably a tissue reaction to the presence of the extract. The presence of glycosides in this plant may have been responsible for this observation (Al-Robai, Abo-Khatwa \& Jamal 1997; Adedapo, Abatan, Akinloye, Idowu \& Olorunsogo 2003).

This study thus showed that the extract of the leaves of Abrus precatorius has potential toxic effects as shown by the effects it caused on the serum chemistry as well as on the changes noted on the organs studied.

\section{REFERENCES}

ABATAN, M.O. AROWOLO, R.O.A. \& OLORUNSOGO, O.O. 1996. Pathological effects of Lantana camara and Dichapetalum madagascariense in goats. Tropical Veterinarian, 14: 127-132.

ADEDAPO, A.A. 2002. Toxicological effects of some plants in the family Euphorbiaceae on rats. Ph.D. thesis, University of Ibadan.

ADEDAPO, A.A., ABATAN, M.O., AKINLOYE, A.K., IDOWU, S. O. \& OLORUNSOGO, O.O. 2003. Morphometric and histopathological studies on the effects of some chromatographic fractions of Phyllanthus amarus and Euphorbia hirta on the male reproductive organs of rats. Journal of Veterinary Science, 4:181-185

AKINLOYE, A.K., IGHARHA, O.O., OLANIYI, M.O., ALAKA, O. O. \& OKE, B.O. 2000. Preliminary investigations on the effects of bitter kola (Garcinia kola) extract on rabbit testes and epididymis. Tropical Veterinarian, 18:49-54.

AL-ROBAI, A.A., ABO-KHATWA, A.N. \& JAMAL, Z.A. 1997. Toxicological studies on the latex of usher plant Calotropis procera (Ait) in Saudi Arabia. V. Seasonal variation of total cardiac glycosides in the usher plant and in various tissues of the usher hopper Poekilocerous bufonius Klug. Arab-Gulf Journal of Scientific Research, 16:129-144.

ATEF, M., NOUSSEF, S.A.H., RAMADAM, A., NAWITO, M.F., EL-SAYED, M.K. \& EL-RAHMAN, H.A. 1995. An influence of phoxim on testicular and seminar vesicle organs, testosterone and cholinesterase level and its tissue residues in male rats. Deutsche Tierärztliche Wochenschrift, 102:301-305.

BUDAVARI, E.D. 1989. The Merck index: an encyclopedia of chemicals, drugs and biologicals, $3^{\text {rd }}$ ed. Rahway: Merck \& Co. Inc.

BURKILL, H.M. 1995. The useful plants of West Tropical Africa. Vol. III. Kew: Royal Botanical Gardens.

BURKILL, H.M. 1997. The useful plants of West Tropical Africa. Vol. II. Kew: Royal Botanical Gardens.

BUSH, B.M. 1991. Interpretations of laboratory results for small animal clinicians. London: Blackwell Scientific Publications.

CARLSON, G.P. 1996. Clinical chemistry tests in Internal animal medicine, edited by B.P. Smith. Boston: Mosby Publishers.

CHEEKE, P.R. \& SHULL, L.R. 1985. Natural toxicants in feeds and poisonous plants., Connecticut: The AVI Publishing Company. 
CHEEKE, P.R. 1998. Natural toxicants in feed, forage and poisonous plants. Denville: Interstate Publishers.

CLARKE, E.G.C. \& CLARKE, M.L. 1975. Veterinary toxicology. London: Balliere Tindall.

COLES, E.H. 1986. Veterinary clinical pathology, $4^{\text {th }}$ ed. Philadelphia: W.B. Saunders Company.

DUNCAN, J.R., PRASSE, K.W. \& MAHAFFEY, E.A. 1994. Veterinary Laboratory Medicine (Clinical Pathology). Ames: lowa State University Press.

ESSEX-SORLIE, D. 1995. Medical biostatistics and epidemiology, $1^{\text {st }}$ ed. Connecticut: Appleton \& Lange.

GALEY, F.D. 1996. Plants and other natural toxicants, in Large animal internal medicine, $2^{\text {nd }}$ ed., edited by B.P. Smith. Boston: Mosby Publishers.

GUNSOLUS, P. 1995. Toxicity of jequirity beans. Journal of the American Medical Association, 157:779.

KLAASSEN, C.D. 2001. Casarett and Doull's toxicology: the basic science of poisoning, $6^{\text {th }}$ ed. New York: McGraw-Hill.

KNOLL, J.S. 1998. Diagnostic procedures for the private practice laboratory, in The Merck Veterinary Manual, $8^{\text {th }}$ ed., edited by S.E. Aiello. Whitehouse Station: Merck \& Co. Inc.

KOHLER-SAMOUILIDIS, G., PAPIOANNOU, N., KOTSAKIKOVATSI, V.P. \& VADARAKIS, A. 1998. The effect of oestradiol valerate on the male reproductive organs and different semen parameters. Frats Berliner und Münchener Tierärztliche Wochenscrift, 111:1-17.

MACFARLANE, P.S., REID, R. \& CALLANDER, R. 2001. Pathology illustrated, $5^{\text {th }}$ ed. London: Churchill Livingstone.
NELSON, D.L. \& COX, M.M. 2000. Lehninger principles of biochemistry, $3^{\text {rd }}$ ed. New York: Worth Publishers.

OLSEN, C.T., KELLER, W.C. \& GERKEN, D.F. 1984. Suspected tremetol poisoning in horses. Journal of the American Veterinary Medical Association, 185:1001-1003.

PIYACCHATUWARATI, P., TIMINKUL, A. \& SUKSAMRAN, A. 1998. Growth suppressive effect of Curcuma comosa. Reproductive Biology, 36:44-49.

RAJARAM, N. \& JANARDHANAN, P. 1992. The chemical composition and nutritional potential of the tribal pulse, Abrus precatorius L. Journal of Plant Food, 42:285-290.

SCHALM, O.W., JAIN, N.C. \& CARROLL, E.J. 1975. Veterinary haematology. Philadelphia: Lea \& Fabiger.

SWENSON, M.J. \& REECE, O.W. 1993. Duke's physiology of domestic animals. Ithaca: Comstock Publishing Associates.

TAHIROV, T.H.O., LU, T-H. \& LIAW, Y-C.1994. A new crystal form of abrin-a from the seeds of Abrus precatorius. Journal of Molecular Biology, 235:1152-1153.

TAIWO, V.O. \& ANOSA, V.O. 1995. Fibrinogen, leukocyte and haematocrit value in cattle with various disease conditions. Tropical Veterinarian, 13:51-58.

TORO, G. \& ACKERMANN, P. 1975. Practical clinical chemistry, $1^{\text {st }}$ ed. Boston: Little Brown \& Co.

WATT, J.M. \& BREYER-BRANDWIJK, A. 1962. The medicinal and poisonous plants of southern and eastern Africa, $2^{\text {nd }}$ ed. London: Livingstone Publishers.

WINDHOLZ, M. 1989. An encyclopedia of chemicals drugs and biologicals, in The Merck index, $3^{\text {rd }}$ ed. Rahway: Merck \& Co. Inc. 